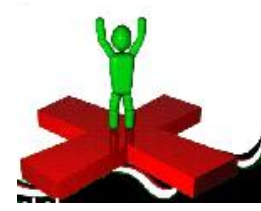

International Journal of Medical Sciences

DOI : 10.15740/HAS/IJMS/8.1and2/25-27 Volume 8| Issue 1\&2 |April \& October, 2015|25-27 e ISSN-0976-7932 | Visit us - www.researchjournal.co.in RESEARCH PAPER

\title{
Comparative analysis of primary metabolites of three medicinal plants
}

\section{G.T. PHEBE, O.P. VERMA AND A.A. CHARAN}

See end of the paper for authors' affiliation Correspondence to : O.P. VERMA

Department of Molecular and Cellular Engineering

Jacob School of

Biotechnology and

Bioengineering, Sam

Higginbottom Institute of

Agriculture, Technology and

Sciences, ALLAHABAD (U.P.)

INDIA

Email: om.verma@

shiats.edu.in

\section{KEY WORDS :}

Soluble sugar, Chlorophyll, Protein, Lipids, Phenols, Starch
ABSTRACT : The plants have long served as a major source of medicinal compounds. Medicinal plants are value added for the contents and the chemical composition of their active components. Therefore, the demand of plant based therapeutics has increased many folds because they are natural products, being non-narcotics, having no side effects and easily available at affordable prices. The goal of the present investigation was to estimate soluble sugar, chlorophyll, protein, lipids, phenols and starch from different plants. The highest amount of protein (46.87\%), chlorophyll (1.63\%) and starch $(57.23 \%)$ was found in Mangifera indica, suluble sugar (68.75) and lipid $(0.03 \%)$ was found highest in Moringa oleifera and the highest phenol $(0.013 \%)$ was obtained from Psidium guajava.

How to cite this paper : Phebe, G.T., Verma, O.P. and Charan, A.A. (2015). Comparative analysis of primary metabolites of three medicinal plants. Internat. J. Med. Sci., 8(1\&2) : 25-27. 